\title{
Buddhism and its Relationship to Dvaravati Period Settlement Patterns and Material Culture in Northeast Thailand and Central Laos $c$. Sixth-Eleventh Centuries A.D.: A Historical Ecology Approach to the Landscape of the Khorat Plateau
}

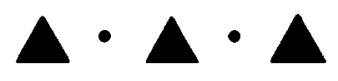

STEPHEN A. MURPHY

\section{INTRODUCTION}

The MAJORITY OF PREvious STUDIES on the development, nature, and spread of early Buddhism throughout Southeast Asia have focused on Buddhist art or archaeological sites. The art history approach primarily looks at issues concerning iconography, style, and influences from India and Sri Lanka, while the site-based archaeology approach usually examines religious architecture, monuments, material remains, and occupational sequences of settlements without necessarily attempting to explain how the wider environment influenced these factors. Consequently, little consideration has yet been given to understanding Buddhism from the wider perspective of its location within the landscape and its relationship to settlement patterns throughout the region, as well as the pivotal role it played in the shaping and trajectory of different societies. Furthermore, Buddhist scholars have focused almost exclusively on textual and epigraphic sources, which tend to be privileged over archaeological or art historical evidence, thus creating an inherent bias in understandings of this religion (e.g., Schopen 1997: 1-22).

These issues are addressed herein by focusing on the emergence and development of Buddhism in areas of northeast Thailand and the Vientiane and Savannakhet provinces of Central Laos during the Dvaravati period (sixth through eleventh centuries A.D.). ${ }^{1}$ Using this region and time frame as a case study, this article employs the theoretical framework of historical ecology coupled with insights and methods derived from landscape archaeology. It illustrates that the relationship between environment 
and settlement patterns is essential to understanding Buddhism, its interaction with society, and its art and architecture. The analytic approach used here shows that the role of Buddhism within society may differ considerably from that which has been proposed based purely on textual, art historical, or site-specific archaeological evidence.

There is some precedence for studies that explain and analyze Buddhism from a landscape perspective. Apart from Moore (2007), most do not deal specifically with Southeast Asia, focusing instead on India, Sri Lanka, or China. Nevertheless, the works of Fogelin (2003), Gunawardana (1971, 1979), Shaw (2004), and Shaw and Sutcliffe $(2001,2003)$ provide the point of departure for this article. While their works are welcome contributions, they all share a common problematic element in their approach; that is, these scholars all view humanity and society as the primary agents in the creation of Buddhist landscapes, agricultural advances, and the emergence of settlement patterns. By taking a historical ecology perspective, however, this article illustrates that environment and ecology play active roles in shaping and sometimes even determining settlement distribution decisions made by societies and their cognitive and physical understandings of the landscapes they inhabit.

This article first looks at the research paradigm of historical ecology in relation to the study of Buddhism and landscape archaeology and discusses how it is applied in this study. Following from this, the interaction between Buddhism and society is described and two forms of monastic praxis are introduced, namely "urban monasticism" and "forest monasticism." Monastic praxis is an essential component in understanding the different ways in which Buddhism functioned in both society and the environment. The article then moves on to looking at settlement patterns and the evidence for Buddhism in the Khorat Plateau during the Dvaravati period. Thirteen specific sites are discussed to illustrate the differing interactions that occur between urban monks and forest monks and their respective social and natural environments. The article concludes by discussing how the role and development of Buddhism in society should be reassessed by taking into consideration not only textual and artistic sources, but also environmental, social, and political conditions.

\section{HISTORICAL ECOLOGY: LANDSCAPE ARCHAEOLOGY AND ITS IMPLICATIONS FOR THE STUDY OF BUDDHISM}

Landscape archaeologists have recently shifted away from treating landscapes as purely physical phenomena to viewing them as cognitive constructs defined largely by how cultures or societies shape, create, and visualize them (Knapp and Ashmore 1999; Layton and Ucko 1999; Tilley 1994). Their approaches to Buddhism and its relationship to the landscape similarly focus primarily on humanity's ability to manipulate and shape its environment to suit its own ends. Landscape archaeologists then situate Buddhism within the anthropocentric setting by illustrating how this religion and its monasteries, architecture, artwork, and monks have all played active roles in physically and cognitively shaping particular landscapes. Buddhism becomes one more agent in the human manipulation and utilization of landscape.

Shaw and Sutcliffe (2001, 2003), for example, show in their survey and analysis of dam construction in the Sanchi area of Madhya Pradesh, Northern India, that the Buddhist sangha (monkhood) oversaw and controlled irrigation and subsequent agricultural production. Their conclusion was reached by calculating the capacity of the 
dams, the scale of possible irrigation the dams could provide, and their spatial layout in relation to the religious structures at Sanchi. Barnes (1999) looks at more cognitive issues of landscape creation. She argues that certain natural features were clearly marked in Buddhist rock and cave art in China and Korea to remove ambiguity from the process of interpretation, resulting in viewers seeing and understanding these features as part of a Buddhist landscape. Fogelin (2003) also looks at spatial placement and lines of sight in interpreting the physical and cognitive landscape of the Thotlakonda monastery and its surrounds in Andhra Pradesh. He then draws inferences regarding the relationship between the sangha and the lay community.

In the examples cited above, only limited attention was given to the ecological and geographical factors at play and the constraints and potentials they provide in regard to the creation of these Buddhist landscapes. In order to overcome this limitation, this article employs the research paradigm of historical ecology. Historical ecology bridges the divide between seeing humanity as the independent shaper of landscapes and seeing nature as the dominant force in determining human society. ${ }^{2}$ As Balée (2006:76) points out, "Historical ecology is a research program concerned with the interactions through time between societies and environments and the consequences of these interactions for understanding the formation of contemporary and past cultures and landscapes." Historical ecologists recognize that there is a dynamic interplay between humanity and the environment. Human beings obviously manipulate their natural surroundings. As technology advances, their ability to shape rather than be shaped by the landscape also increases. This article particularly looks at technological advances in areas such as water management and agriculture as seen in the construction and management of canals, moats, and irrigation systems. Technological advances also include the ability to create more visible and monumental architecture, including rock-cut caves and sculptures as well as free-standing structures such as stupas (Buddhist reliquaries or commemorative mounds or monuments), viharas (assembly halls), and ubosots (ordination halls); these features in turn transform the physical and natural landscape.

To obtain "a historical understanding of human activities in the environment and how the environment itself came to be," historical ecology allows for multiscalar geographical and temporal perspectives (Balée and Erickson 2006:12). Buddhist sites and landscapes must be viewed within both local and regional contexts as well as short- to long-term temporal frameworks. These are essential in any study that wishes to understand and document the spread and development of Buddhism in a given area or region.

There now follows a discussion on the relationship between Buddhist monasticism and society and how established views and presumptions about this phenomenon can be challenged and reassessed in light of the insights derived from landscape archaeology and historical ecology approaches.

\section{BUDDHIST MONASTICISM AND SOCIETY: VIEWS FROM HISTORIC AND ETHNOGRAPHIC RECORDS}

The archaeological remains discussed here, such as sema stones (Buddhist boundary markers), Buddha images, and moated sites, provide the best surviving evidence for studying the relationship between Buddhism, local communities, and patronage dynamics. Early studies of Buddhism gave primacy to the written word; however, as 
scholars strove to understand the religion through examining texts that had been handed down and survived from antiquity, they developed a viewpoint of Buddhist monasticism as removed from society and essentially functioning in isolation. They argued that the ultimate goal for all Buddhist monks was to withdraw completely from society in all its facets in their struggle to attain individual enlightenment through meditation and an ascetic lifestyle. Scholars such as Marshall, Foucher, and Majumdar (1940) found support for their views in texts such as the Anguttara Nikaya (Thera and Bodhi 1999:v, 17) that strictly forbade the sangha from involving themselves in worldly affairs. In reality, Buddhist sanghas and societies have always existed in mutually interdependent relationships. Sanghas rely on Buddhist lay communities to provide daily sustenance and the basic necessities of life. Monasteries cannot survive without the active participation of their local communities. In general, the larger the monastery, the larger (or wealthier) the lay community needed to sustain it (Bunnag 1991: 166).

The lay community is meanwhile dependent on the sangha to perform religious rituals and rites of passage, such as funerals and marriage ceremonies, as well an essential educational role, particularly in regard to writing and literacy (Bechert and Gombrich 1991:13-14; Bunnag 1991:167). Perhaps even more important to the sangha and laity alike in modern Thai Buddhism is the obtaining of merit by means of making donations at ceremonies such as the Kathina ceremony (Swearer 1995:23-25).

Powerful social and political factors can come into play in the complex relationship between the sangha and society. In many instances in both South and Southeast Asia, past and present, royal patronage has played a key role in the development and spread of Buddhism (Bunnag 1991 :161-163). Emperor Asoka's conversion to the religion in the third century B.C., for example, facilitated its spread throughout his substantial empire in India (Chakrabarti 1995:196-197). The sangha in turn could legitimize the royalty whose patronage they received. Being able to declare that a king was a chakravartin (an idealized universal Buddhist monarch) or dhammaraja (a king who rules in accordance with the teachings of the Buddha) would be a powerful tool in the hands of an astute Buddhist monk. ${ }^{3}$ The reciprocal arrangements that developed between royalty, the lay community, and the sangha further strengthened the bond between society and Buddhism.

That some monks might have actively sought to live in wealthy urban centers in hope of receiving patronage seems at odds with the Buddhist canon. Indeed, not all members of the sangha took such pragmatic approaches to participating in society. Some attempted to strictly follow the spiritual ideals at the heart of Buddhist texts by retreating from large-scale, usually urban-based, monasteries. They resided instead in forests, rock shelters, caves, or on mountainsides. This tradition of "forest monks" has a long history in South and Southeast Asia, and is still practiced to this day in countries such as Sri Lanka, Thailand, and Burma (Conningham 1995; Tambiah 1984). In comparison to their urban counterparts, who are largely dependent on local communities for support, forest monks can choose to withdraw almost completely from society for long periods of time. As a result, they have no direct ties with the lay community.

While choosing isolation over interaction necessarily limits the size of the population of forest monks at their retreat sites and their ability to create monumental architecture or high-quality Buddhist art, forest monks nevertheless could gain spiritual prestige among lay believers. Their retreats sometimes became pilgrimage sites where they were sought out for their spiritual or supernatural powers (Conningham 
1995:232-235). Forest monks thus interacted with society differently than urban monks. The mountaintop sites discussed herein could have fulfilled either function as retreat from society or pilgrimage center.

The two different forms of Buddhist monasticism are clearly visible in the archaeological record of India and Sri Lanka. Gunawardana (1971:24) provides evidence for what has been termed "monastic landlordism" in Sri Lanka in the form of ancient dams that have inscriptions linking them to monasteries in their vicinity. The inscriptions describe how the Buddhist monasteries were in possession of substantial tracts of land donated by local rulers and private donors. Furthermore, Buddhaghosa, writing in the fifth century A.D., describes how in cases where the sanghas received irrigation systems as gifts, they would take over the running and management of these works (Gunawardana 1971:57-59). This suggests that the sanghas were actively involved in agricultural activities. Shaw and Sutcliffe (2003) have investigated similar phenomena in Sanchi. They argue that the control of water harvesting and irrigation facilities in the surrounding area from the third to second century B.C. onward was both a means of obtaining political legitimization by local rulers, who were the major donors, and a key strategy of urban monks to propagate their religion $(2003: 75)$. They argue that:

[The sangha] were not so much concerned with "converting" local populations, but rather offered a set of practical incentives for locals to give their economic support to the monastery. The promise of religious merit is usually posited as the main incentive for buying into this new scheme; there were also worldly advantages such as the promise of increased yields and improved nutrition. (Shaw and Sutcliffe 2003:82)

Some of the most reliable early evidence for the tradition of forest monasticism comes from Sri Lanka, where there exist over a thousand cave dwellings datable by inscriptions from the third century B.C. to the first century A.D. (Conningham 1995:228-229). Interestingly, these caves were offered as acts of merit, with 30 percent of them being donated by local chiefs. Forty-seven percent of the donations have been classified as donated by "others," while only just over 6 percent were donated by royalty (Conningham 1995:230). It appears therefore that forest asceticism was supported mainly by local communities, not large urban centers, in Sri Lanka.

Evidence for royal patronage of Buddhism in the Khorat Plateau comes in the form of inscriptions on two sema stones. For instance, according to Cha-em's (1989:235) reading of Inscription K404 from Ban Kaeng Village in the Kaset Sombun district of Chaiyaphum Province, at least one high-ranking individual who was known for her moral integrity and "dharma-filled wisdom" was interested in acquiring beneficial karma. Cha-em proposes that the person in question was named Cudamani, and that she was possibly a queen who gave important support to a certain King Srijayasimahavarman. Although this inference is not entirely supported by surviving epigraphic evidence (cf. Murphy 2010a:268) and it is not possible to identify the exact names of the individuals involved, it remains plausible that the dedication of the semas was as much an act of religious merit as an assertion of political power.

The Hin Khon inscription (K388) also concerns royalty involved in Buddhism. It was set up by a prince who had become a monk (rajabhiksu). He not only dedicated four semas made of high-quality stone but also gave large donations to the sangha (Filliozat 1981:84; Woodward 2005:104). It is therefore clear that Buddhist monks in the Khorat Plateau were tapping into circles of political power in order to help propagate and embed the religion within society at large. 
The evidence and discussion presented above illustrates that the traditional textbased view of Buddhism as functioning in isolation from society is largely an ideal that was usually only achieved in practice by forest monks. The tradition of forest monks functioning on the periphery of society would not have facilitated, and does not explain, the widespread distribution of Buddhist communities or the emergence of monumental Buddhist art and architecture. Furthermore, the evidence from Sri Lanka, Sanchi, and the Khorat Plateau all suggest that patronage came primarily from lay communities wishing to partake in the merit-making process and local rulers seeking to increase or perhaps maintain legitimacy.

\section{RESEARCH SETTING: THE SPREAD OF BUDDHISM IN THE KHORAT PLATEAU DURING THE DVARAVATI PERIOD}

The Khorat Plateau as defined in this article encompasses the regions of northeast Thailand and the lowland areas of Central Laos. ${ }^{4}$ The Khorat Plateau lies at an average height of about $170 \mathrm{~m}$ above sea level and dominates the physical geography of the area. It is bordered by the Phetchabun and Dangrek mountain ranges to the west and south, respectively, and to the north and east by the course of the Mekong River and the Troung Son Cordillera mountain range in central and southern Laos (Fig. 1).

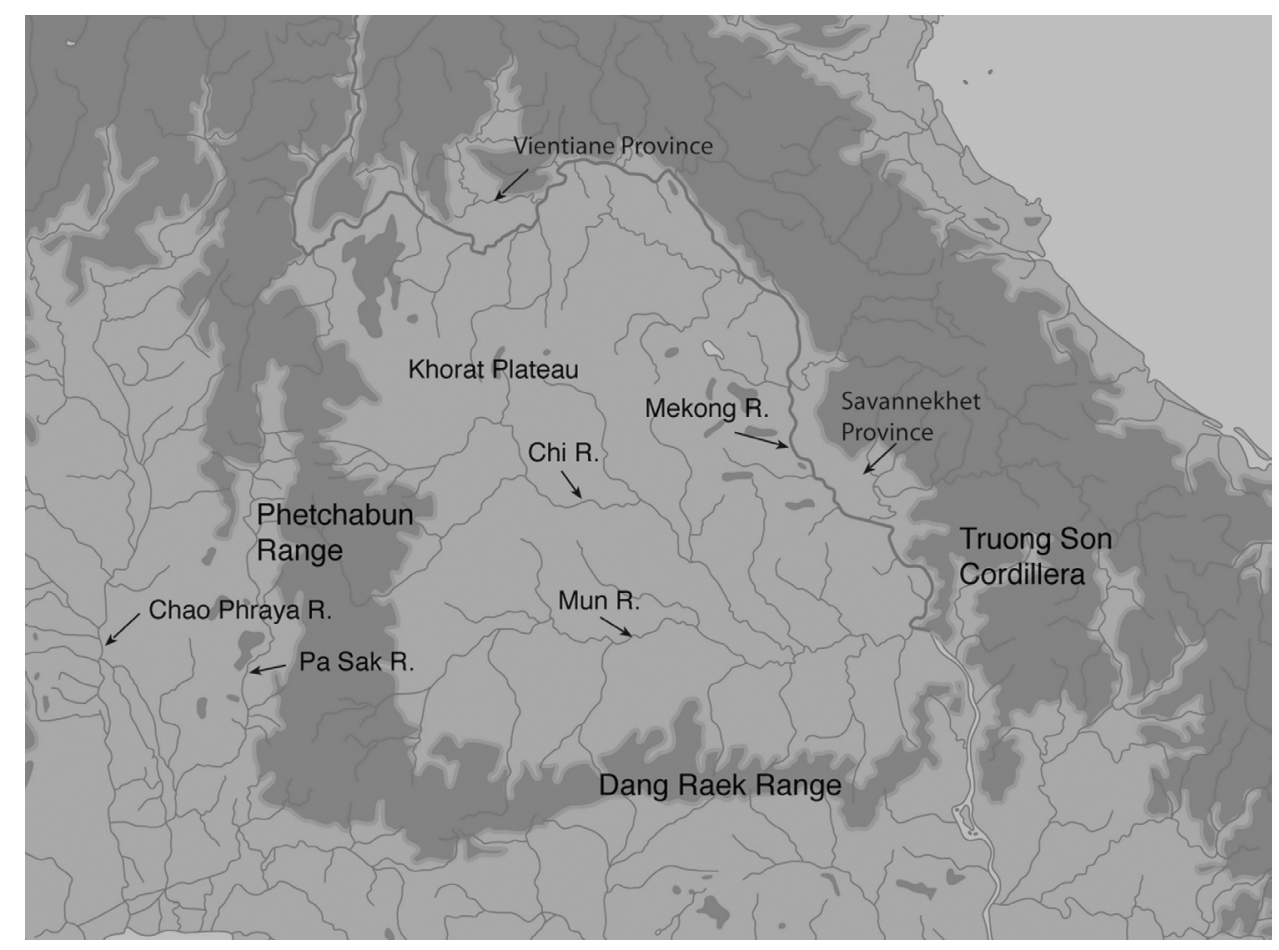

Fig. 1. Map of the Khorat Plateau showing major river systems and mountain ranges. (Adapted from a base map courtesy of River Books.) 
Unlike Thailand's great alluvial plain, which is drained by the Chao Phraya River and provides excellent conditions for rice cultivation, the Khorat Plateau is ill-suited for this type of agriculture. Soils are poor in quality and prone to salinity. Furthermore, rainfall throughout the region is irregular, resulting in drought and flooding at various times throughout the year (Kermel-Torres 2004:162). It is unsurprising, therefore, that the majority of early archaeological sites, including those of the Dvaravati period, are located along tributaries or within close proximity to the Chi, Mun, or Mekong river systems. These river systems are characterized by wide alluvial valleys, with the Mun and Chi Rivers in particular stretching across almost the entire length of the region. The moated sites discussed here are located almost exclusively along these river systems, indicating the essential role that these waterways played not only in the distribution of settlement patterns throughout the region but also in regard to the spread and establishment of Buddhism.

\section{THE SPREAD OF BUDDHISM IN THE KHORAT PLATEAU}

\section{DURING THE DVARAVATI PERIOD}

This article now discusses the spread of Buddhism to the Khorat Plateau during the Dvaravati period. It argues that the dissemination of Buddhism into the region largely followed the distribution of preexisting settlements, while recognizing that there were two types of Buddhist sites in the region: urban monasteries and forest monk sites. The location of monasteries was largely restricted to urban settlements. Forest monk sites were less bounded, and spread into areas that were less densely populated and less dependent on agricultural production.

To track the trajectory and spread of Buddhism in the region, three major forms of evidence are analyzed in this article: moated sites, earthen mounds, and sema stones. Moated sites represent the major urban settlements of the period and are therefore the key locations into which Buddhism spread. Earthen mounds are normally associated with moated sites; upon excavation, they usually turn out to be Buddhist structures of some kind (e.g., stupas). The third form of evidence is sema stones or Buddhist boundary markers (Murphy 2010a). These large objects, usually carved out of sandstone or sometimes laterite, are found throughout the region. They represent one of the best forms of surviving evidence for the spread of Buddhism into the Khorat Plateau. Data were collected during survey work carried out in the region by the author from October 2007 to November 2008 (Murphy 2010b).

This research documented 45 Dvaravati period moated sites in the Khorat Plateau, some of which have origins in prehistoric periods (Fig. 2). The distribution of the Dvaravati period moated sites reveals their dependence on the Mun and Chi river systems, since all but three are located on these two rivers or their tributaries. The courses of these tributaries and streams are usually adapted to feed the moats either for flood control or irrigation purposes. The placement on or near these river systems would also have played a vital role in terms of trade, transport, and communication.

Moated sites consist of single or multiple moats, usually accompanied by a rampart; the sites themselves span between 40 and 170 ha (Supajaya and Vanasin 1983). Some sites, such as Muang Sema, evolved and expanded over time, with additional moats added to increase the interior area of the settlement (Moore 1988:9). 


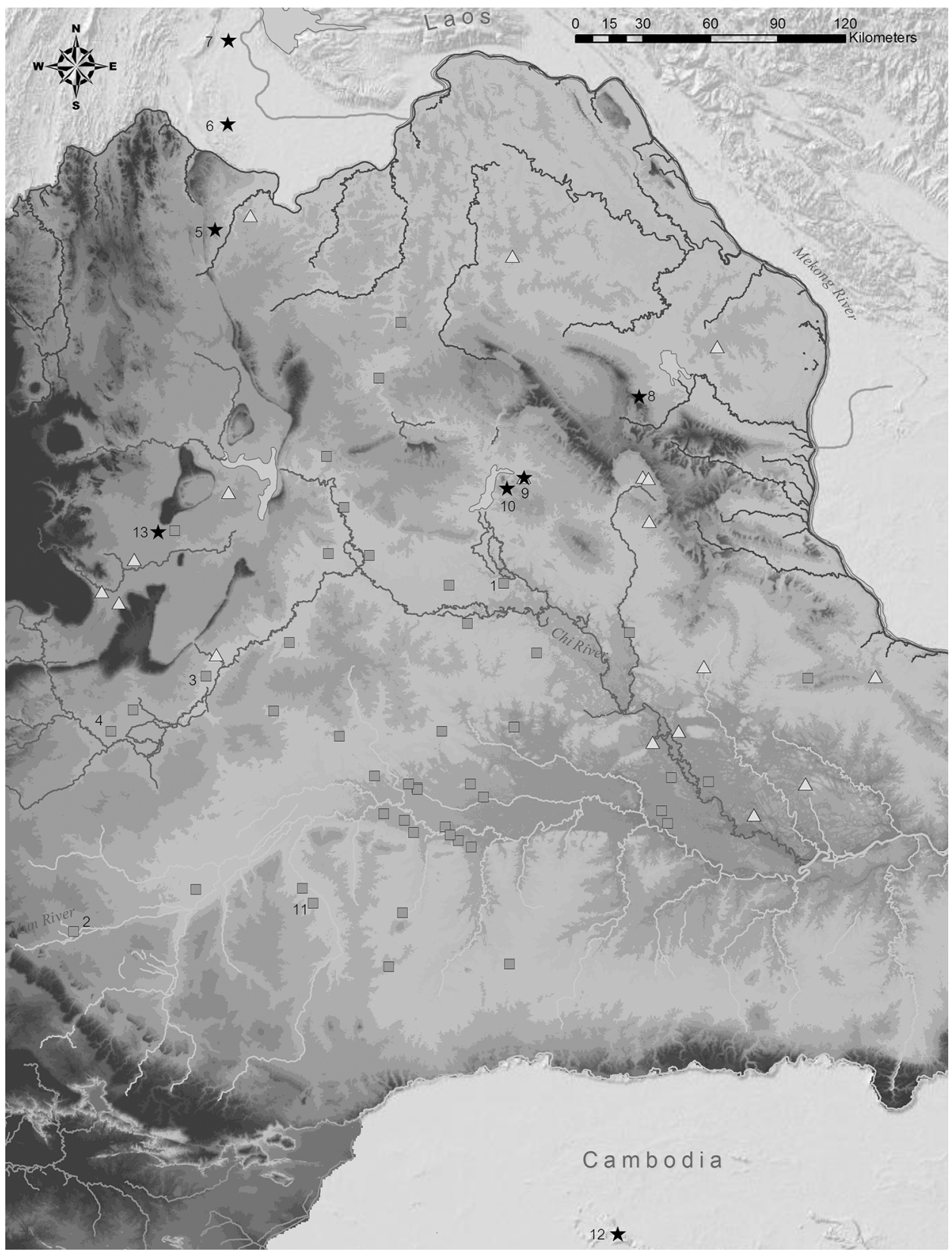

Fig. 2. Map showing the Khorat Plateau and the distribution of moated sites (squares), earthen mounds (triangles), and mountaintop sites (stars). Sites discussed in this article: 1. Muang Fa Daed, 2. Muang Sema, 3. Ban Khon Sawan, 4. Ban Kut Ngong, 5. Phu Phra Bat, 6. Dan Sung, 7. Vang Sang, 8. Wat Doi Thepharat, 9. Wat Phu Putthanimit, 10. Phu Bor, 11. Ban Muang Fai, 12. Phnom Kulen, 13. Phu Wiang. 
Religious structures such as stupas are clearly present at five of these sites; further archaeological investigation of other sites could reveal similar evidence. Earthen mounds are located at moated sites in numerous instances. However, 18 of the earthen mounds surveyed are not located within this site type. These earthen mounds may represent hinterland settlements consisting of small-scale communities. Consequently there is much less evidence of Buddhist remains at these earthen mounds than amongst those found at moated sites.

Sema stones provide a unique means of tracking the spread and location of Buddhism in the Khorat Plateau during the Dvaravati period, with 110 sites and over 1200 of these monumental stone objects documented to date (Murphy 2010b:145146; 2013). Sema stones are present at 26 out of the 45 moated sites discussed here (Fig. 3).

The function of semas is to demarcate Buddhist ritual space. During this period, they were usually placed around ubosots, stupas, and sometimes Buddha images (Murphy 2010a:268). Some forms of Buddhist religious architecture, such as ubosots and viharas, have not survived as they were usually made of perishable material, such as bamboo and straw weave (Krairiksh 1974:42; Murphy 2010a:274). Since semas are made of a durable substance, they survive to this day. The presence of semas is a clear indication that a functioning Buddhist community once existed at a site. The number of semas indicates the size of the Buddhist community. Some sites with earthen mounds have between 8 to 15 semas, indicating that monasteries were located within small rural communities. Large-scale moated sites such as Muang Fa Daed have over 170 semas, indicating that a large Buddhist community was present. The presence or absence of artwork on semas is another important indicator in tracking the growth of Buddhism in the region. Semas carved with high-quality Buddhist art, usually jataka tales (stories about previous incarnations of the Buddha), represent well-developed Buddhist sanghas receiving active patronage from lay believers and local rulers. Semas lacking art or designs of any considerable artistic merit imply lessdeveloped Buddhist communities.

The two maps shown in Figure 2 and Figure 3 reveal that the majority of moated sites, earthen mounds, and sites with sema are located on or nearby the major river systems of the Mun, Chi, and Mekong. Large river systems in Southeast Asia functioned as primary means of transportation, communication, and trade, so large-scale settlements were usually located on and dependent upon these geographic features. This returns us to historical ecology, a research paradigm that allows us to consider how environmental factors helped shape and determine the spread of Buddhism. The size, characteristics, and agricultural potential of sites in the Khorat Plateau during the Dvaravati period would have had a direct impact on the ability of Buddhism to spread within the region. If monasteries wished to maintain large populations of monks, they needed sufficiently large lay communities to support them. Lay communities had to be producing sufficient surpluses of food and other resources to support monastic communities. Therefore, large-scale monasteries could only flourish in areas that had sufficient agricultural resources owing to their location in regard to river systems in the region. The spread and growth of Buddhism was therefore to a certain extent dependent upon and determined by ecological factors and how effectively these factors could be harnessed, not only by local lay communities but most likely by the sangha as well. 


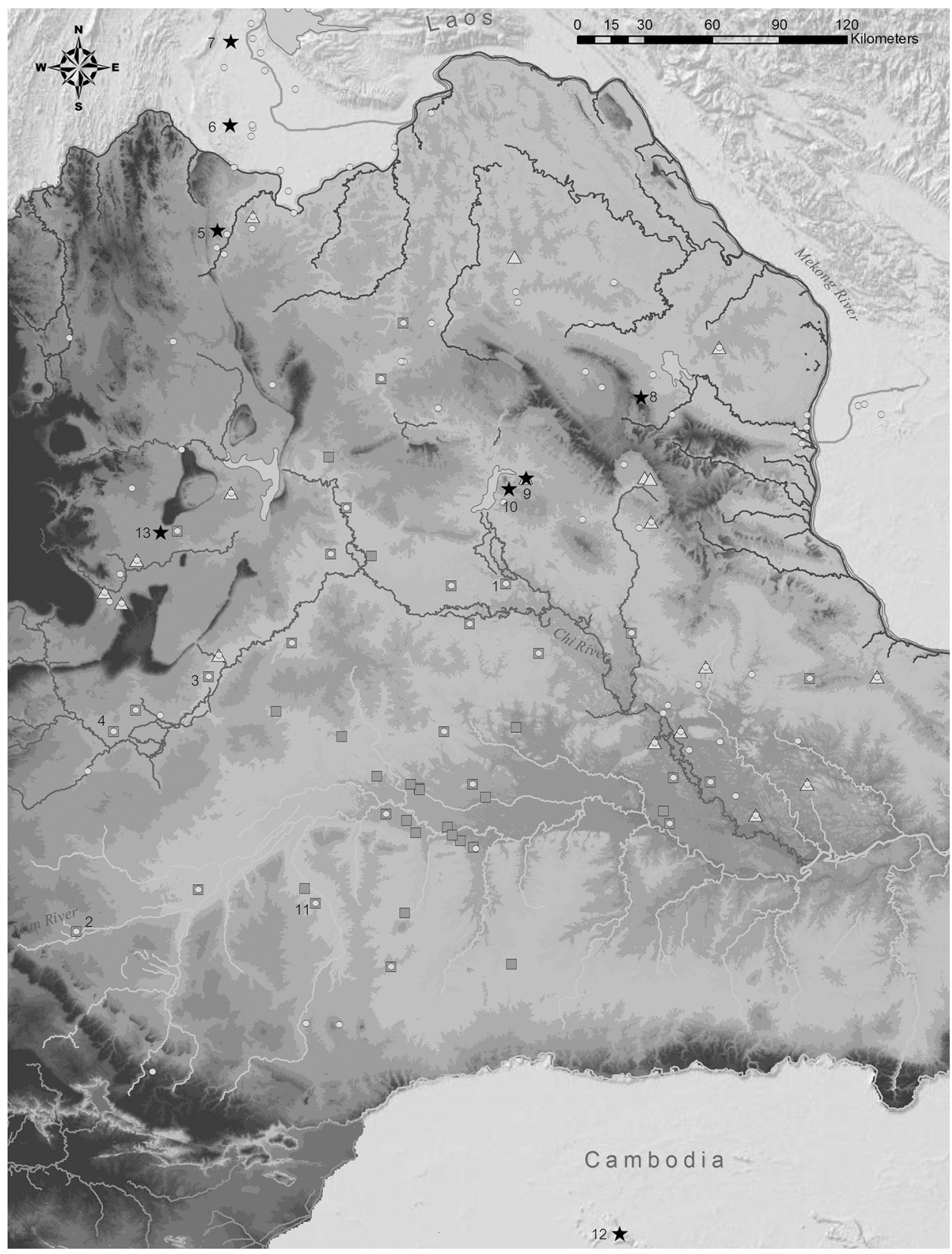

Fig. 3. Map showing the Khorat Plateau and the distribution of moated sites (squares), earthen mounds (triangles), mountaintop sites (stars), and sema stone locations (circles). Sites discussed in this article: 1. Muang Fa Daed, 2. Muang Sema, 3. Ban Khon Sawan, 4. Ban Kut Ngong, 5. Phu Phra Bat, 6. Dan Sung, 7. Vang Sang, 8. Wat Doi Thepharat, 9. Wat Phu Putthanimit, 10. Phu Bor, 11. Ban Muang Fai, 12. Phnom Kulen, 13. Phu Wiang. 
Forest monks, on the other hand, survived largely independently of lay communities. Small groups living an ascetic lifestyle needed little in the way of food or donations from local communities to support them. They were therefore less dependent on ecological factors and could choose anywhere they wished to live. The environment nevertheless determined their choice of retreat sites. Their primary criterium for their retreats was isolation. If there were no suitable mountains or caves in the vicinity, a monk might choose to retreat into the forest instead. Alternatively, if there was little forest cover in the area due to swidden agricultural activities or intensive rice farming, a monk might choose a mountain or hilltop for his retreat. Only in the sense of having their choices restricted was this type of monk dependent on the environment.

This division into two site types, urban and forest monasticism, can be observed in the archaeological record and in the site distribution patterns of the period and region under discussion here. The majority of Buddhist remains, such as stupas, ubosots, semas, Buddha images, and votive tablets come from large-scale moated sites. As a rule, the larger the site, the denser the evidence for Buddhism in the area. Furthermore, moated sites at this time were located almost exclusively along two major river systems, the Mun and the Chi. Forest monk sites, on the other hand, were located away from the major river systems and moated sites, illustrating their relative independence from these ecological and anthropological features. They were primarily found on hilltops, mountaintops, and forested mountainsides. As discussed below, in a number of instances, these sites include images carved into the rock face of the Buddha reclining in the mahaparinirvana posture. ${ }^{5}$

It has been noted already that moated sites in the Khorat Plateau have a long history, dating back as far as the Bronze Age. It is generally agreed that settlements were located primarily within the moats in prehistoric times. However, following the arrival of Buddhism, an interesting change occurs in the settlement plans of moated sites. At a number of major sites, Buddhist monuments are located both inside and outside the moats. This phenomenon is discussed in detail below.

\section{CASE STUDIES}

A number of key sites found throughout the Khorat Plateau are now discussed to illustrate the characteristics of both urban monasticism and forest asceticism. The five moated sites to be discussed are Muang Fa Daed, Muang Sema, Ban Kut Ngong, Ban Khon Sawan, and Ban Muang Fai. The eight mountaintop sites showing potential evidence of forest monasticism are Phu Phra Bat, Vang Sang, Dan Sung, Wat Phu Kao Putthanimit, Phu Bor, Phu Wiang, Wat Doi Thepharat, and Phnom Kulen (Fig. 2). The five moated sites illustrate the nature and extent of Buddhist remains present at settlements of this type, while the eight mountaintop sites are evidence for the existence of isolated Buddhist groups that withdrew from society.

These sites were chosen for analysis because they provide some of the best available examples and evidence for the emergence and existence of Buddhism in the Khorat Plateau. It must be noted, however, that the choice of sites was based on information and data available at present. To date, the majority of archaeological research in the Khorat Plateau has focused on prehistoric periods, while comparatively little research has been done in historic periods such as the Dvaravati. Much further work therefore 
needs to be done throughout the region to provide a clearer picture of this formative period in both the history of Thailand and Buddhism.

\section{Moated Sites}

Muang Fa Daed - Measuring 171 ha in total, Muang Fa Daed was one of the largest Dvaravati period settlements in the Khorat Plateau. Situated on the Pao River, a tributary of the Chi, it was not only close to a steady and reliable water supply, it also occupied an advantageous position in terms of trade and transportation along the river system, facilitating access to the Sakhon Nakhon basin to the north and the Chi river system to the south. The site represents a flourishing Buddhist culture within the Khorat Plateau. This is evident in the extent of Buddhist remains, including 14 stupas, an ubosot, and over 170 sema stones, many of which display high-quality Buddhist art.

In order for Buddhism to have taken hold to such an extent, the sangha must have had the active support of the lay community and, most likely, the rulers of Muang Fa Daed themselves. The location of the ubosot, a key monastic building, is particularly suggestive of a dynamic relationship between the sangha and the lay community. It is located close to the center of the site on an east-west orientation (Indrawooth $2001: 104$, map 1). Only a sangha that was willingly and actively participating in society would choose to locate its monastery in such a central and prominent area of the settlement.

With the establishment of Buddhism at the site, we observe changes taking place in urban planning and the layout of the settlement. Seven stupas were placed directly outside the moat, in effect ringing it (Indrawooth 2001:104, map 2). This is an important cognitive shift in the way landscape was constructed and viewed. Prior to the arrival of Buddhism, there seems to have been a clear separation between inside and outside the moat. However, with the flourishing of this religion, the divide was altered somewhat. Instead, we see religious structures being placed outside the moat, acting to define the extent and limits of the settlement (compare location of stupa remains in Figs. 4 and 5). This calls into question the idea that the moats were primarily defensive, as it appears that by the Dvaravati period the settlement had expanded beyond these watercourses. However, it is still possible that the moats could have provided protection for the inhabitants, as those located outside of them could take refuge within if external threats arose.

The placement of religious structures such as the seven stupas surrounding the site and the ubosot located in a central position illustrate that by the Dvaravati period, Buddhism had firmly established itself within this major settlement. Furthermore, the extent of the monumental architectural remains and the high-quality artwork found throughout the site (best exemplified on the sema stones) suggests that Buddhism was receiving a great deal of patronage from the settlement's elite and ruling classes by this time.

Muang Sema - The large moated site of Muang Sema is located on the Lam Ta Khong River, part of the Mun river system, in Sung Noen district, Nakhon Ratchasima Province. It covers an area of over 150 ha (Moore 1988:9). The site has been divided into three phases of occupation (Wangsuk 2000 : iv). The earliest phase dates from the fourth to the fifth century and shows similarities in material culture with the Late Prehistoric 


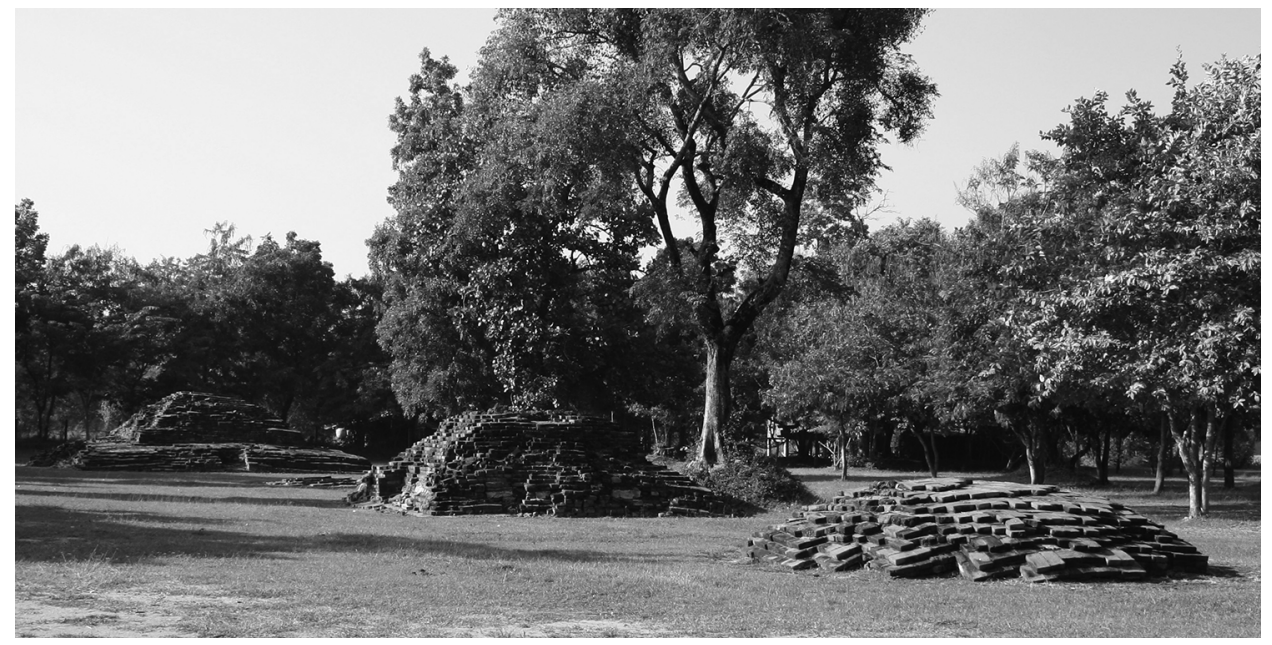

Fig. 4. Ruined superstructures of three brick-built stupas located within the interior of the moat at Muang Fa Daed, Kalasin Province.

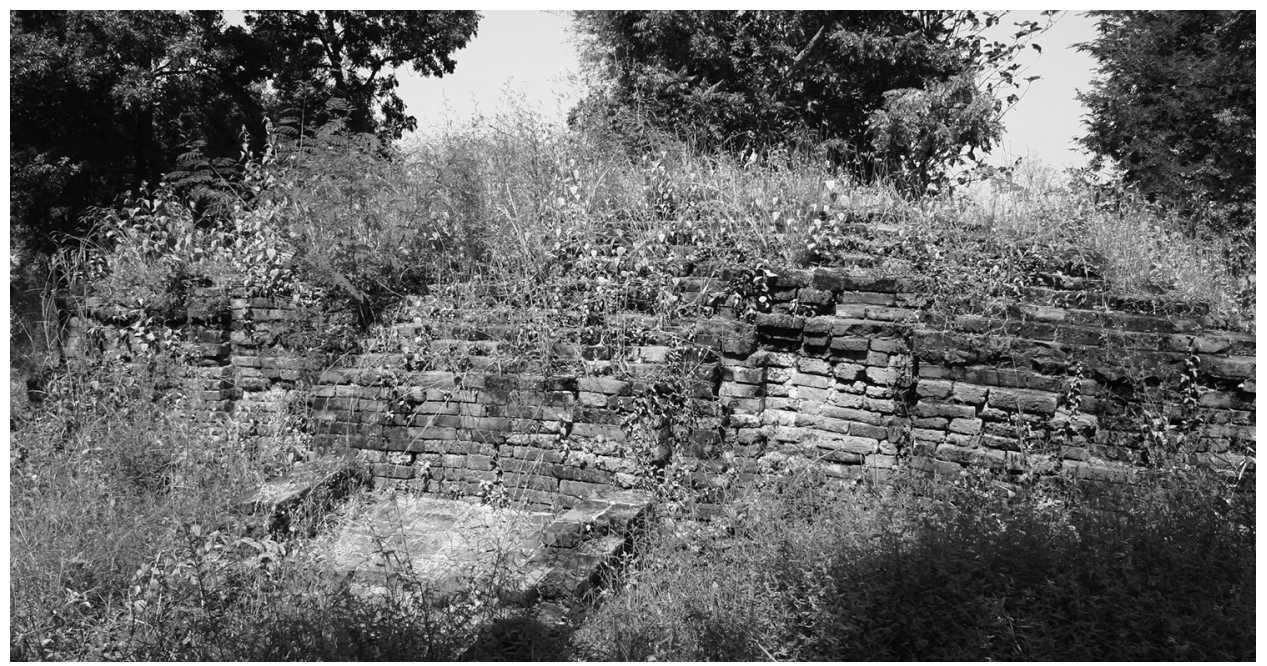

Fig. 5. Ruined superstructure of Stupa no. 9 from Muang Fa Daed. This brick-built stupa is located on the northeastern exterior of the moat.

period, particularly in regard to the Phimai Black pottery that was discovered during the course of excavations. The second phase dates from the sixth to the ninth century and represents the period in which Buddhism was adopted at the site. The third phase, from the ninth to the twelfth century, shows evidence of growing Khmer influence as indicated by the presence of Buriram ceramics and Sung dynasty ware.

The site originally consisted of one moat; however, a second was added during the third phase with a Khmer prasat (temple) located at the center, greatly increasing the area of the settlement. It is clear from the archaeological record that the area enclosed 
by the first moat dates to the Dvaravati period and remained in use throughout the occupation of the site (Wangsuk 2000). However, it is unclear when exactly the second moat was added. As no excavations have been carried out on this feature to date, further research is needed to clarify this issue.

As with Muang Fa Daed, Muang Sema shows ample evidence for the adoption of Buddhism. Perhaps the best-known archaeological feature from this site is an $11 \mathrm{~m}$ long sandstone sculpture of a Buddha lying in the mahaparinirvana posture. A replica image is located in front of it and is covered in gold leaf. Both images are still worshipped today and are surrounded by offerings such as flowers, candles, and incense. The site is also known for the discovery of a dharmacakra (wheel of law) sculpture in close vicinity to the Buddha image. ${ }^{6}$ Excavations carried out by the Fine Arts Department of Thailand and the National Museum in 1980 focused on the area surrounding the image of Buddha in mahaparinirvana posture that is situated some $500 \mathrm{~m}$ outside of the moat (Wangsuk 2000:42-43). The excavations revealed the foundation of a large building $(6.50 \times 26 \mathrm{~m})$ that originally housed the Buddha image. The building was a two-room structure classifiable as a vihara. The main room held the Buddha image, and a small room at one end perhaps functioned as an antechamber.

Excavations in 1999 focused on nine monuments, seven of which were located within the moat with the remaining two (Monuments 8 and 9) located just outside the northern moat. Five of these interior monuments turned out to be small Dvaravati period stupas, either four-sided or eight-sided in design, ranging from $6.12 \times 6.40$ $\mathrm{m}$ to $6.70 \times 10.90 \mathrm{~m}$ in size. Monuments 8 and 9 on the exterior also appear to be small stupas.

Monument 1 is the largest structure at the site, and is situated roughly in the center of the settlement. It measures $45 \times 50 \mathrm{~m}$ and has an entrance facing south (Wangsuk 2000 : 44-46). It most likely represents a vihara, and therefore the center of a monastery. The ground plan of Monument 4, measuring $8.25 \times 13.50 \mathrm{~m}$, led Wangsuk $(2000: 45)$ to identify it as another vihara. She noted, however, that it was surrounded by sema stones. Since semas usually demarcate ubosots rather than viharas, it is more likely that this building was an ubosot (Murphy 2010a). This interpretation is strengthened by the fact that Monument 1 appears to be a vihara. A monastic complex usually required both a vihara and an ubosot. The former was usually the larger of the two buildings, as it functioned as a place where the lay community could gather to pray or hear sermons. The ubosot only needed to be large enough to accommodate the monks as they performed prescribed rites and rituals. It seems therefore most likely that Monument 1 was the vihara and Monument 4 the ubosot.

The seven monuments located within the moat lie within close proximity to each other, none being farther than $100 \mathrm{~m}$ apart. The presence of a vihara, an ubosot, and numerous stupas located close to the center of the site illustrates a monastic community firmly situated within the urban framework of Muang Sema (Wangsuk 2000:209, map 1). However, as with Muang Fa Daed, religious structures are also located outside the moat. Monuments 8 and 9, the Buddha image, and a vihara $500 \mathrm{~m}$ to the southwest again suggest that Buddhism played a key role in altering the cognitive and physical landscape of settlement patterns.

The extent and positioning of the Buddhist remains at Muang Sema illustrate the close relationship established between the sangha and the lay community. The resources needed to construct the viharas and the Buddha image would have called for substantial donations and almost certainly patronage from the settlement's ruling elite, 
once more emphasizing the reliance of the sangha upon the urban milieu in which it found itself.

Ban Kut Ngong and Ban Khon Sawan - Ban Kut Ngong and Ban Khon Sawan are both located in Chaiyaphum Province in close proximity to the Chi river system. ${ }^{7}$ They both illustrate the presence of Buddhism at urban settlements. Since no comprehensive archaeological excavations have taken place at either site, the evidence for Buddhism comes from the presence of sema stones, not religious structures. The large numbers of these objects discovered at both sites, and the level of artistic execution exhibited on these stones, reveal that Buddhist communities were present and most likely interacting with the lay community in ways similar to the Muang Fa Daed and Muang Sema sites.

For instance, there are 27 sema stones at Ban Kut Ngong, 10 of which are carved with illustrations of jataka tales. Two sema show a high level of artistic skill in the execution of these images. They are as aesthetically fine as the art that was then being produced in the Dvaravati heartland of Central Thailand (Fig. 6). A similar phenomenon is observed at Ban Khon Sawan, where out of 42 sema located at this site, 12 are carved with jataka images. The presence of numerous sema at both sites indicates that there was a relatively large monastic community present. Furthermore, the quality of the artwork points to the presence of highly skilled artists. It can be concluded that active support was given to the sangha by the lay communities at both these sites. Acquiring large quantities of high-quality stone and running an artistic workshop would not have been achievable by the monastic community alone. It is much more likely that the stone was obtained and donated by the lay community, or (as Inscriptions K404 and K388 suggest) by wealthy patrons or rulers.

Ban Muang Fai - This is a large moated site in Buriram Province. ${ }^{8}$ Although no systematic excavations have taken place to date, four significant finds suggest this was a Buddhist site. These finds include three bronze statues and one stone statue. Two of the bronze statues represent Bodhisattva Maitreya (the future Buddha or Buddha-tobe); the third depicts the Buddha in a standing posture. The stone statue shows a Buddha seated under a naga (serpent deity in both Hinduism and Buddhism) (Diskul 1971). The bronze standing Buddha image and one of the Maitreya images are each over a meter tall and exhibit extremely accomplished artistic and technical abilities. Images of this quality could only be produced by highly skilled artisans, operating out of an established workshop that we can presume was located at the Ban Muang Fai site. Therefore, we can infer that the lay community present at Ban Muang Fai was actively engaging in Buddhist religious practices. The ability to produce such highquality bronze and stone images also indicates a considerable degree of patronage and support. Once again this illustrates that the Buddhist sangha and lay community were actively interacting with each other, and that considerable local resources (such as bronze, stone, and wood) were being channeled into Buddhist religious activities.

The five moated sites discussed above suggest that Buddhism had spread into the Khorat Plateau by the Dvaravati period and become firmly established at key settlements in the region. The scale and sophistication of the architectural remains, artwork, and religious images present at these sites would only have been possible through large-scale donations and patronage from the lay community and local rulers. The quality of the artwork on sema found at Muang Fa Daed, Ban Kut Ngong, and Ban Khon Sawan, and the bronze casting skills represented by the Ban Muang Fai 


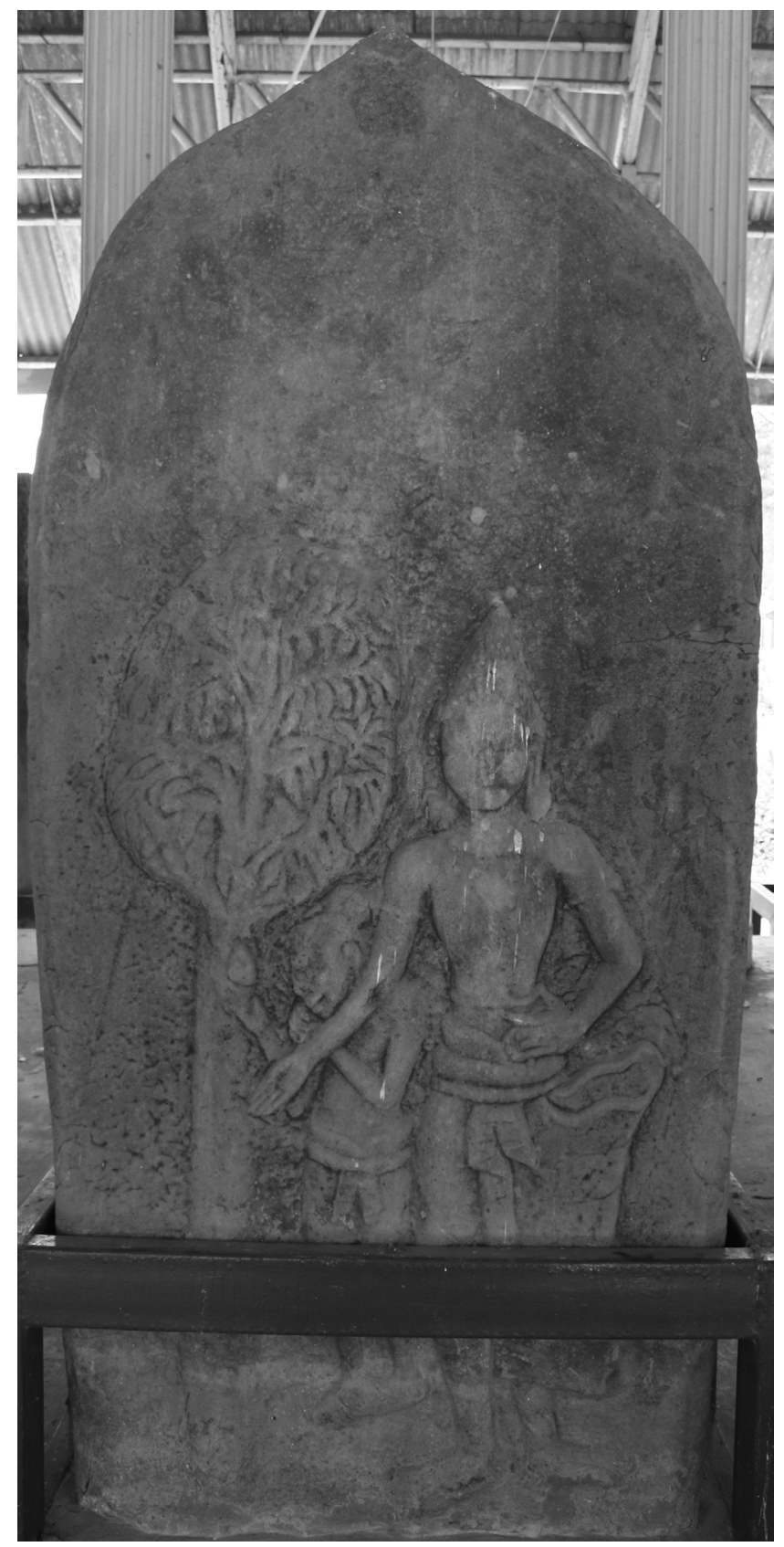

Fig. 6. Sema stone from the site of Ban Kut Ngong in Chaiyaphum Province depicting the Vessantara Jataka tale. 
images could only have been produced in established workshops that required considerable investment. It is unsurprising that this scale and level of production is only found at large moated sites. The production of Buddhist art was therefore not only dependent on spiritual concerns but also influenced by environmental, agricultural, economic, and political factors.

A further significant feature associated with the arrival of Buddhism was the alteration of the landscape of moated sites. The construction of religious structures outside of moats suggests that earlier conceptions of interior versus exterior had changed and the physical and cognitive understandings of the landscapes of such settlements reconfigured.

\section{Mountaintop Sites}

Phu Phra Bat - This site is located on the Phu Phan mountain range in Ban Phue district, Udon Thani Province. The mountain range is still covered with hardwood forest today, which indicates what the environment must have been like during the Dvaravati period. The site covers an area of about $10 \mathrm{~km}^{2}$, and is at an average height of 320-350 m above sea level, rising 120-160 m above the plain below. It shows evidence of both prehistoric and early historic (Dvaravati period) habitation (Chutiwongs 2000 : 48). Numerous rock shelters throughout the site exhibit prehistoric wall paintings; evidence for Buddhism comes in the form of sema stones and Buddha images carved into the rock face.

There are 23 Buddhist sites spread out across the top of the mountain range, suggesting there was a sizable monastic community here during the Dvaravati period. Prior to their use as Buddhist habitats, these shelters were used by prehistoric inhabitants. The placement of sema stones around many of these structures could have been an attempt to "Buddhisize" these formerly "animistic" locations. The sites consist of rock shelters adapted for habitation with little use of permanent building material such as brick. Due to natural erosion, many of the rock shelters have quite unusual shapes that seem to defy gravity: they can be described as somewhat mushroom-like in that they are slender in the middle and have wide, overhanging tops. Chutiwongs has suggested that these rock formations may have been chosen by Buddhist monks not only for their practical value to provide shelter, but also for their mystical appeal (2000:43). Geological and environmental factors such as this therefore also help us to understand the appeal of certain locations over others.

The most remarkable rock shelter is known today as Usa's Tower. It consists of a natural rock formation combined with a brick structure that creates a small chamber, with one door and two windows (Fig. 7). It most likely functioned as a monk's cell, which was perhaps accessible by ladder. Many of the rock shelters have been worked to form suitable places for meditation. Usually their floors have been leveled and smoothed, or their roofs dug out, to allow for a person to stand within the shelter; some were large enough to accommodate up to ten monks at a time. One location particularly emphasizes the spiritual inspiration that can be provided by natural settings. A seat for meditation has been carved out of the natural rock in a shaded spot at the edge of a cliff, with views of the plains below, providing an ideal environment for spiritual contemplation (Chutiwongs $2000: 46$ ).

The site of Phu Phra Bat represents one of the best examples in Southeast Asia of a monastic forest community in existence during antiquity. Based on the number of 


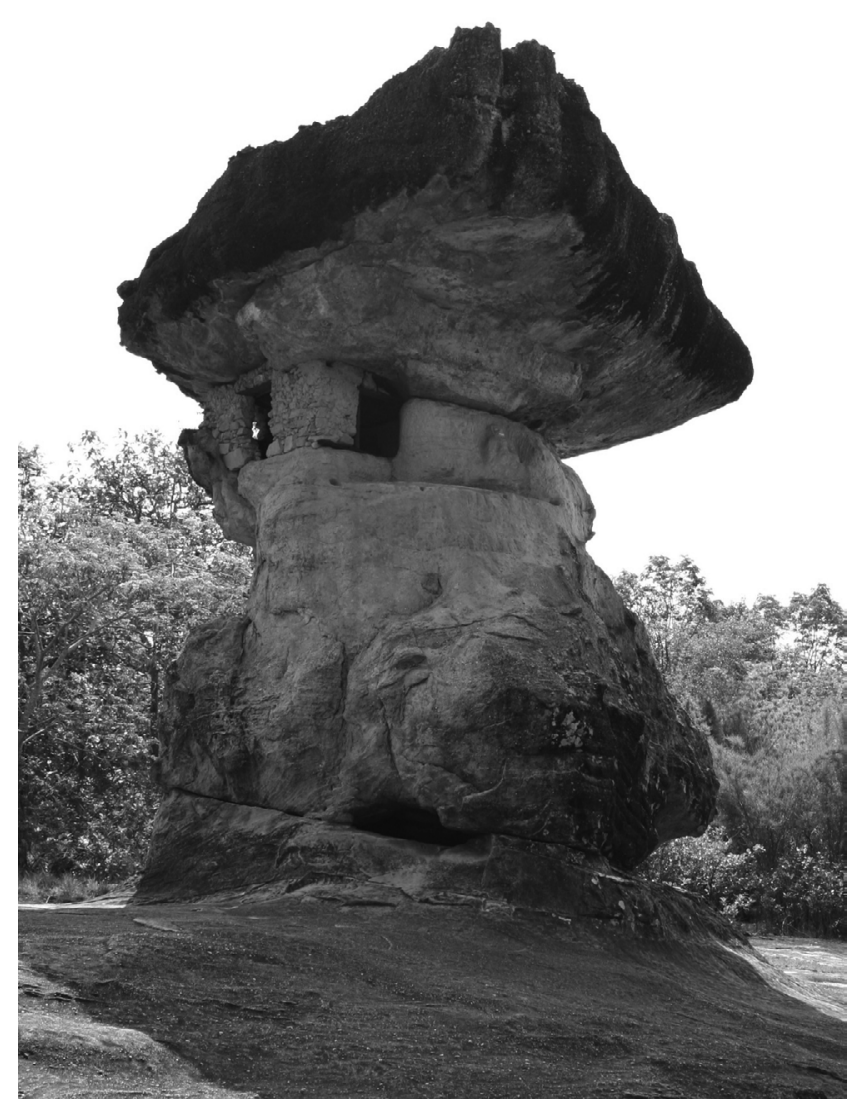

Fig. 7. A rock shelter known today as Usa's Tower, at the archaeological site of Phu Phra Bat.

rock shelters present and that each shelter could house between two and ten monks, we may estimate that up to one hundred monks could have inhabited the site at any given period. The presence of naturally occurring rock formations suitable for remodeling into habitats, a plentiful water supply, ample forest cover, and the relative isolation of the hilltop all made Phu Phra Bat an ideal choice for those withdrawing from society in order to seek spiritual enlightenment.

Connection with the lowland Buddhist communities would still have taken place, to a limited extent. In the area directly surrounding the Phu Phan mountain range there were numerous Buddhist sites along the river systems, particular the Huai Mong River, a tributary of the Mekong where six lowland sites have been located (Murphy 2010b:173-174) (Fig. 3). The monks from these communities could have spent time in retreat at Phu Phra Bat, particularly during the rainy season (the traditional period for retreat). Pilgrimage to Phu Phra Bat by the lay community was also a likely activity. Forest monks may have been specifically sought out in the belief that they had superior spiritual or even mystical powers compared to their lowland counterparts (Conningham 1995:232-235). Therefore, while the site of Phu Phra Bat was separate from lowland settlements, it was not entirely disconnected from them. 


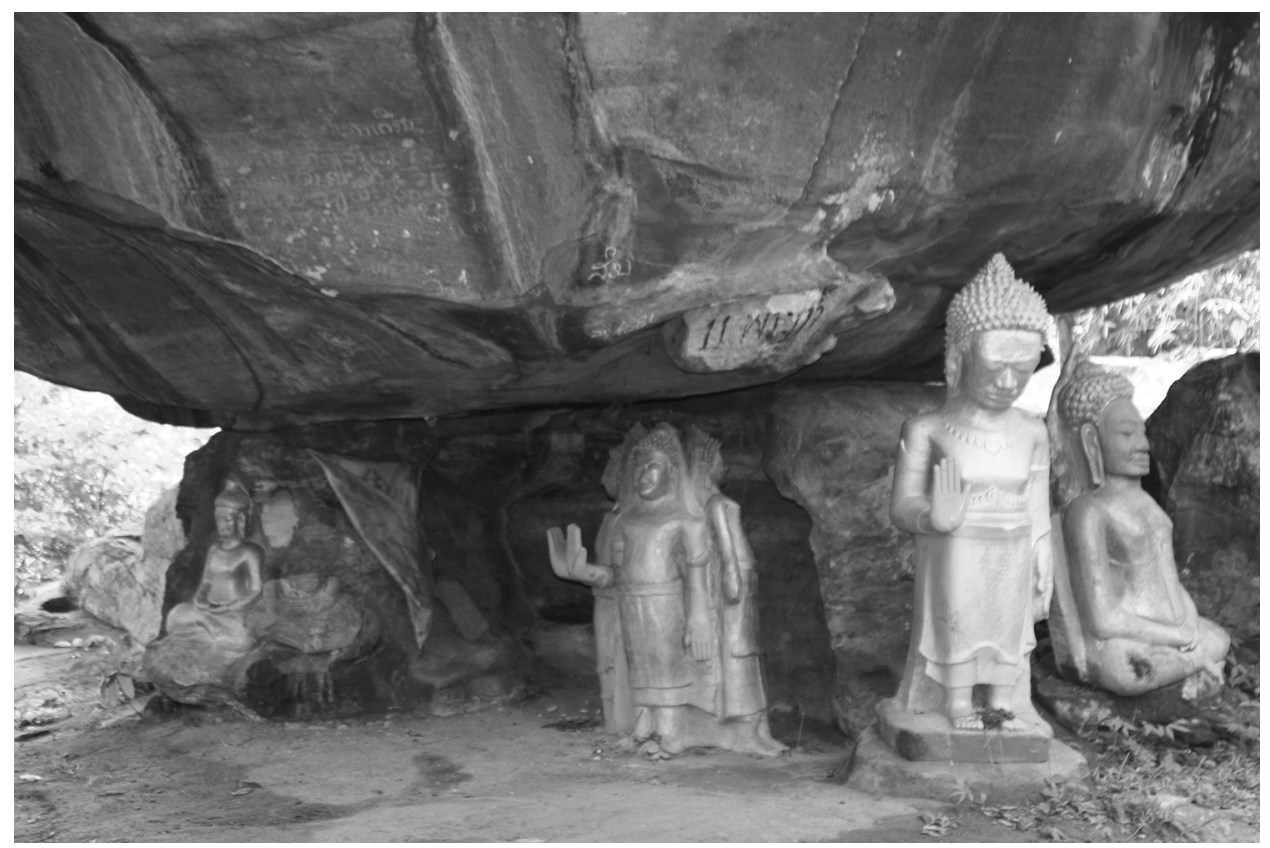

Fig. 8. Rock shelter with Buddha images covered in modern gold paint at the site of Dan Sung, Vientiane Province, Laos.

Dan Sung and Vang Sang - These two sites in Vientiane Province of Laos are very similar in their location and characteristics to Phu Phra Bat. Dan Sung is located approximately $50 \mathrm{~km}$ to the north of Phu Phra Bat, while Vang Sang is approximately $40 \mathrm{~km}$ farther north again. Both sites are located in mountain foothills and, as at Phu Phra Bat, have numerous Buddha images carved into the rock face, forming small grottos (Lorrillard 2008: 116-127, 168, 172) (Fig. 8). Stylistically the Buddha images are similar to those found at Phu Phra Bat, being classifiable as Dvaravati art; however, a number of them also show some Khmer features and may thus be somewhat later in date, circa tenth to eleventh century (Lorrillard 2008).

These two sites were clearly following similar spiritual practices and traditions to the monks of Phu Phra Bat, and their geographical proximity suggests that these sites may have been part of the same tradition of forest monks that began to emerge in the Khorat Plateau around the seventh to eighth century onward. Furthermore, like Phu Phra Bat, both sites were located close to lowland Buddhist communities, once again suggesting pilgrimage and connection between the two (see Fig. 3).

Phu Wiang, Phu Bor, Wat Phu Kao Putthanimit, Wat Doi Thepharat, and Phnom Kulen - Evidence for Buddhism spreading from the lowlands to the highlands is further attested by five sites that possess images of the Buddha in mahaparinirvana posture. Images have been carved into overhangs in the rock face at the top of the mountains on which Phu Bor, Phu Wiang, and Wat Phu Kao Putthanimit are located (Fig. 9). As with Phu Phra Bat, the surrounding mountainsides are heavily forested today, allowing us to infer that a similar environment existed during the Dvaravati period. Phu Wiang, Phu Bor, and Wat Phu Kao Putthanimit are all located along the Chi 

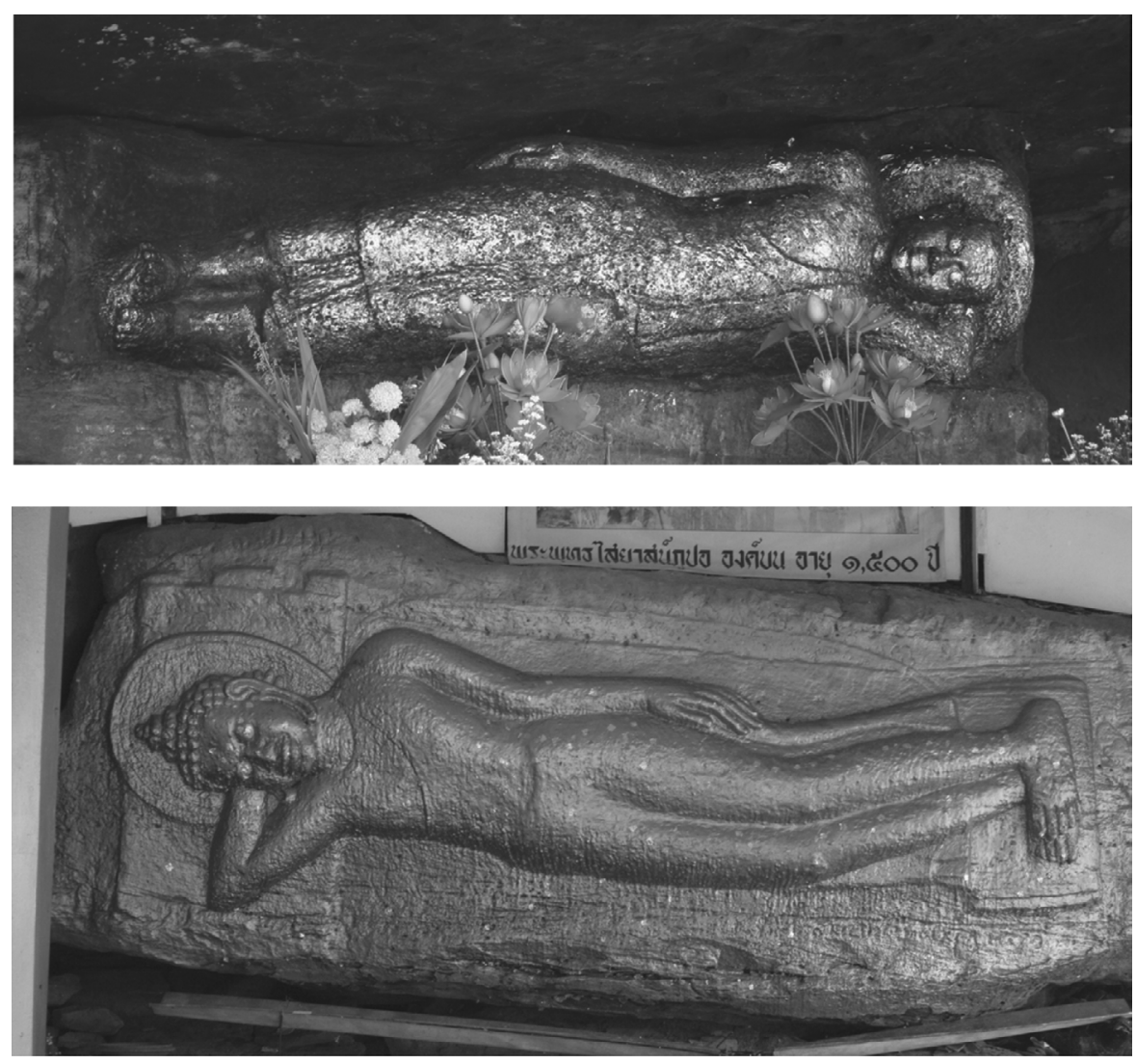

Fig. 9. Top: Buddha image in mahaparinirvana carved into the rock face at Wat Phu Kao Putthanimit. Bottom: Buddha image in mahaparinirvana carved into the rock at Phu Bor.

river system, close to two of the densest concentrations of lowland Buddhist sites (Murphy 2013:218-223). ${ }^{9}$ Phu Wiang, for instance, is in close proximity to the moated site of Ban Non Muang, while Phu Kao Putthanimit and Phu Bor in Kalasin Province would most likely have fallen within Muang Fa Daed's sphere of influence.

At Phu Wiang the Buddha image is approximately $3.70 \mathrm{~m}$ long, and a Ye Dhamma inscription in Old Mon dating to c. ninth century CE is located underneath. ${ }^{10}$ The site itself is approximately $340 \mathrm{~m}$ above the surrounding plains and provides a commanding view of the landscape below. The site of Wat Phu Kao Putthanimit also possesses excellent views of the plains below, and evidence for the existence of a monastic community is further attested to by Dvaravati sema stones found at the site. Their presence indicates that there was probably also some form of religious structure present, most likely an ubosot or vihara.

Another statue of the Buddha in mahaparinirvana posture is located at Wat Doi Thepharat, in the Huai Yang subdistrict, Muang district, Sakhon Nakhon Province. It is located at the foot of the mountainside, approximately $20-30 \mathrm{~m}$ above the plain. The area is still forested at present, although rice farms now reach the foot of the mountain. 
An example outside the Khorat Plateau should be mentioned for comparative purposes. On the top of Phnom Kulen Mountain in Cambodia, approximately $50 \mathrm{~km}$ outside Angkor, a small Buddhist community existed between the eighth and ninth centuries. This is evident by the presence of sema stones at two separate sites, Tun Mas and Ban Gre (Boulbet and Dagens 1973). Close to these sites is located a Dvaravati style Buddha image in mahaparinirvana carved into the rock face. ${ }^{11}$

These five locations with images of Buddha in mahaparinirvana most likely functioned as isolated communities of forest monks, similar to those operating at Phu Phra Bat, Vang Sang, and Dan Sung. The sema stones from Wat Phu Kao Putthanimit in particular indicate the presence of a Buddhist community. However, as with the latter three sites, these locations may also have functioned as pilgrimage sites for nearby lay communities. Their relative proximity to lowland settlements, the presence of Buddha images carved into the rock face, the natural forest environment, and the panoramic views offered of the plains below would all have enticed lay believers to make pilgrimages to these sites. Add to this the presence of forest monks, most likely held in high esteem by lay believers, and the argument for pilgrimage becomes stronger. Therefore, while the sangha at these sites would have lived in relative isolation, a certain degree of interaction with the wider secular world was still a distinct possibility.

The choice to portray the Buddha in mahaparinirvana in mountain locations is an interesting one. Apart from the example at Muang Sema, no other Buddha images in this posture have been found at lowland sites in the Khorat Plateau during the Dvaravati period. The fact that at Phu Wiang, Phu Bor, Wat Phu Kao Putthanimit, Wat Doi Thepharat, and Phnom Kulen the Buddha was depicted in this fashion indicates that it must have had a particular significance to these forest monks. It also illustrates a certain commonality of tradition among the monks who inhabited these isolated sites.

All eight forest retreat sites discussed here represent a form of Buddhist monasticism that favored some degree of isolation from society. Not reliant on the patronage of the lay community or local rulers, these members of the sangha were freer to choose where to locate- be it in the foothills, or on mountainsides, or on forested mountaintops-than their urban brethren. Withdrawing from society allowed them to spread into areas not reliant on agricultural factors such as the ability of the land to produce sufficient yields, or settlements that needed to be located along important lines of communication such as major river systems. However, without the support of large lay communities, forest monks were unable to create significant monumental architecture. Instead, they carved Buddha images into rock faces and altered natural formations such as rock shelters to become their habitats. These remote sites could not sustain large populations of monks because of the lack of lay donations and food resources. This factor, along with their isolation, meant that the ability of forest monks to propagate Buddhism would have been limited compared to their brethren in large lowland settlements. Although monks residing at the upland sites removed themselves from lowland secular society, there may still have been relatively frequent communication between them and urban sangha. These forested sites may have been used as annual rainy season retreats by lowland monks who sought out forest monks for instruction in meditative techniques.

To sum up, during the Dvaravati period in the Khorat Plateau, Buddhism was predominately a lowland tradition. Urban monasticism seems to have dominated the major lowland settlements, where elite patronage and lay support allowed for the creation of monumental architecture and the flourishing of Buddhist art. Buddhist 
monastics of this kind were largely restricted to substantial moated sites located along major river systems, however. The highlands and mountaintops were home to another form of Buddhist monasticism in which monks shunned regular interactions with lay society and instead chose to isolate themselves in their quest for spiritual enlightenment. In this sense, the forest monks more closely match the descriptions of Buddhist monastic practice given in textual sources than urban monks.

\section{CONCLUSION}

Historical ecology allows us to view the landscape as a record of both the intentional and unintentional modifications created by humans on the environment (Crumley 2007 :17). It also emphasizes that we should not perceive humanity and nature as constantly in opposition to each other. Instead, a reciprocal dynamic exists between society and the environment (Balée and Erickson 2006:9). By viewing Buddhism in this light, new understandings and interpretations arise. While forest monastic practices may be in greater harmony with nature than urban monasticism, even these ascetic practices cause some change and modification to the environment. Carving religious imagery into rock faces and adapting rock shelters for habitation leave permanent traces on the natural surroundings. On the other hand, in actively expanding and reshaping moated sites, urban monastics leave much more indelible marks on the surrounding landscape.

By analyzing the distribution of moated sites, earthen mounds, and sema stones, this article has shown that settlement patterns in the Khorat Plateau during the Dvaravati period were largely determined by environmental factors, in particular the courses of major river systems and the availability of sufficiently fertile agricultural land to support high population levels and produce surplus food. At the same time, people in these settlements modified and manipulated their natural surroundings. The creation and maintenance of moated sites represented a considerable altering of the environment and allowed these societies to utilize water resources, not only for irrigation and flood control but, just as importantly, for transport and communication.

The arrival of Buddhism further reshaped the cognitive and physical landscapes. In wanting to propagate their religion, Buddhist sanghas sought to live in large-scale moated sites so they could acquire patronage and donations from lay communities and local rulers. The support of the lay communities allowed them to alter the landscapes of the moated sites; monumental architecture arose in the form of stupas, ubosots, and viharas. We can infer that sites such as Muang Fa Daed, Ban Muang Fai, and Muang Sema were producing high agricultural yields and using the surplus to support the flourishing of Buddhist art, which would have required considerable stone and metal resources. At the same time, a cognitive shift in landscapes occurred as structures began to be built, both inside and outside the moats. Muang Fa Daed, for example, is ringed by stupas, and Muang Sema also has significant religious structures located outside the moat.

Comparative evidence from Sri Lanka and India suggests that the sangha may also have played an active role in agricultural production, including introducing new irrigation techniques and management skills. The paucity of epigraphic remains in the Khorat Plateau makes it impossible to know whether the sanghas in this region were also actively engaged in agriculture, although it would explain their prominent positioning within these urban centers. 
Not all of the sanghas may have had such close ties with the lay community. Some chose to withdraw from society in their quest for spiritual enlightenment. Such forest monks carried Buddhism into areas that were relatively inaccessible to laypeople and undesirable to their urban counterparts. Seeking out mountaintops, hillsides, and forested areas, they interacted with the natural environment in different physical and cognitive ways. They nevertheless also "Buddhisized" their landscapes such that the highlands came to be viewed as locations for asceticism, meditation, and pilgrimage.

By spreading into the lowlands along the river systems and settling in major urban centers, Buddhism altered the physical and cognitive landscapes of the Khorat Plateau. Buddhist architecture began to dominate the skyline. Constructing stupas both inside and outside the moats facilitated a cognitive change in how the boundaries of settlements were understood. The tradition of forest monasticism transformed the landscape in a different way. Retreating to isolated regions, forest monks allowed natural features such as mountain ranges, forests, and hilltops to enter and become part of the greater Buddhist sacred landscape. This transformation was not only cognitive but physical, as attested by the remains of the many Buddhist images carved into the rock faces. Through these differing ways, Buddhism spread into both lowland and highland areas of the Khorat Plateau and forever transformed its landscape into a representation of the three jewels of Buddhism: the Buddha, the Dharma, and the Sangha.

\section{ACKNOWLEDGMENTS}

Many thanks to Chureekamol Onsuwan Eyre, Ben Marwick, Elizabeth Moore, and Leedom Lefferts for their critical comments and feedback on this article. Additional thanks go to the Department of Asian Art at the The Metropolitan Museum of Art in New York for funding my participation in the 77th Annual Meeting of the Society for American Archaeology, during which I presented this paper.

\section{NOTES}

1. For a recent discussion on the definitions and debates surrounding the term Dvaravati, see Skilling (2003). For an overview of the archaeological evidence, see Indrawooth (1999). For definitions of the Dvaravati art style, see Dupont (1959), Boisselier (1975), and Woodward (1997). For issues regarding dating the Dvaravati period, see Barram and Glover (2008) and Glover (2010).

2. Historical ecology is thus different from cultural ecology, which sees the environment as immutable and forcing human cultures, technology, and populations to adapt to it rather than the other way around.

3. Emperor Asoka best exemplifies a chakravartin ruler.

4. This definition is somewhat wider than the more conventional one, which usually only refers to Northeast Thailand. It can be argued that the definition presented here is valid since the modern political divide centering on the Mekong River obscures the geographical homogeneity of the region (Murphy 2010b:126-130). The Mekong River should be seen as a vital route of communication, transport, and trade as opposed to a modern boundary between nation-states. Early Buddhism was not subjected to such nineteenth-twentieth-century political divisions, and was free to spread along both sides of this river system. Note that Central Laos comprises the provinces of Vientiane, Xaysomboun, Xiengkhuang, Borikhamxay, Khammoune, and Savannakhet as well as the prefecture of Vientiane city (Sisouphanthong and Taillard 2000:14-15).

5. The mahaparinirvana posture represents the moment that the Buddha passed away and entered nirvana, the ultimate cessation of being. In Buddhist iconography, this moment is depicted by the Buddha lying down on his side, with his head either resting on his hand, a pillow, or both.

6. A dharmacakra (wheel of the law) is a spoked wheel symbolizing the Buddha's sermon at the deer park in Sarnath. This symbol became prevalent in the sculptural traditions of the Dvaravati period, particularly in Central Thailand (Brown 1996). 
7. Ban Kut Ngong is located in Na Ngong Chaeng subdistrict, Muang district. Ban Khon Sawan is located in Ban Khon Sawan subdistrict, Khon Sawan district.

8. Ban Muang Fai is located in Lam Plai Mat district, Buriram Province.

9. Both Phu Bor and Wat Phu Kao Putthanimit temple are located in Sahat Sakhan district in Kalasin Province. Phu Wiang is located at Ban Nohn Sa-aht, Chai Sor subdistrict, Chum Phae district, Khon Kaen Province.

10. Ye Dhamma is a formulaic Buddhist votive prayer found on many Dvaravati artifacts such as votive tablets and dharmacakras.

11. It appears that while the dominant state religion at the time was Hinduism, Buddhism to a certain extent managed to exist in isolated pockets.

\section{REFERENCES CITED}

BaLÉe, William

2006 The research program of historical ecology. Annual Review of Anthropology 27 : 75-98.

Balée, William, and Clark L. Erickson

1999 Buddhist landscapes of East Asia, in Archaeologies of Landscape: Contemporary Perspectives: 101123, ed. Wendy Ashmore and A. B. Knapp. Oxford: Blackwell Publishers.

2006 Time, complexity and historical ecology, in Time and Complexity in Historical Ecology: Studies in the Neotropical Lowlands: 1-20, ed. William Balée and Clark L. Erickson. New York: Columbia University Press.

Barnes, Gina L.

1999 Buddhist landscapes of East Asia, in Archaeologies of Landscape: Contemporary Perspectives: 101123, ed. Wendy Ashmore and A. B. Knapp. Oxford: Blackwell Publishers.

Barram, ANDrew, and Ian Glover

2008 Re-thinking Dvaravati, in From Homo Erectus to the Living Traditions: Choice of Papers from the 11th International Conference of the European Association of Southeast Asian Archaeologists, Bougon, 25-29 September: 175-182, ed. J. Pautreau, A. Coupey, and V. Zeitoun. Chiang Mai: Siam Ratana.

Bechert, Heinze, and Richard Gombrich

1991 The World of Buddhism: Buddhist Monks and Nuns in Society and Culture. London: Thames \& Hudson.

BOISSELIER, JEAN

1975 The Heritage of Thai Sculpture. Bangkok: Asia Books.

Boulbet, J., ANd Bruno Dagens

1973 Les sites archeologiques de la region du Bhnam Gulen [Archaeological sites in the region of Phnom Kulen]. Arts Asiatiques 27:1-130.

BROWN, ROBERT

1996 The Dvaravati Wheels of the Law and the Indianization of Southeast Asia. Leiden: Brill.

BunNAG, JANE

1991 The way of the monk and the way of the world: Buddhism in Thailand, Laos, and Cambodia, in The World of Buddhism: Buddhist Monks and Nuns in Society and Culture: 159-170, ed. Heinze Bechert and Richard Gombrich. London: Thames \& Hudson.

Cha-em, Kaeokhlai

1989 Sila charuk Phu Khio an lae plae mai [A new reading and interpretation of the Phu Khio inscription]. Silpakorn 29(3): 64 (in Thai).

Chakrabarti, Dilip

1995 Buddhist sites across South Asia as influenced by political and economic forces. World Archaeology 27(2): 185-202.

Chutiwongs, Nandana

2000 Phu Phra Bat: A remarkable archaeological site in Northeast Thailand. Journal of the Siam Society $88: 42-52$.

Conningham, Robin A. E.

1995 Monk, caves and kings: A reassessment of the nature of early Buddhism in Sri Lanka. World Archaeology 27(2): 222-242. 
Crumley, Carole L.

2007 Historical ecology: Integrated thinking at multiple temporal and spatial scales, in The World System and the Earth System: Global Socioenvironmental Change and Sustainability Since the Neolithic: 15-28, ed. Alf Hornborg and Carole L. Crumley. Walnut Creek, CA: Left Coast Press.

Diskul, M. C. Subhadradis

1971 The Buddha and the Snake King. Hemisphere 15(5):32-35.

DUPONT, P.

1959 L'Archeologie Mone de Dvaravati [The Mon Archaeology of Dvaravati]. Paris: L'Ecole Francaise d'Extreme-Orient.

Filliozat, JeAN

1981 Sur le Çivaisme et le Bouddhisme du Cambodge [Shaivism and Buddhism in Cambodia]. BEFEO 70:59-99.

FOGELIN, LARS

2003 Beyond the Monastery Walls: The Archaeology of Early Buddhism in North Coastal Andhra Pradesh, India. Ph.D. diss. University of Michigan. Ann Arbor: ProQuest/UMI (Publication No. ATT 3096095).

GLOver, IAN

2010 The Dvaravati gap - Linking prehistory and history in early Thailand. Bulletin of the Indo-Pacific Prehistory Association 30:79-86.

GunAwardana, R.A.L.H.

1971 Irrigation and hydraulic society in early medieval Ceylon. Past and Present 53:3-27.

1979 Robe and Plough: Monasticism and Economic Interest in Early Medieval Sri Lanka. Monographs of the Association for Asian Studies, No. 35. Tucson: University of Arizona Press.

INDRAWOOTH, PHA

1999 Dvaravati: A Critical Study Based on the Archaeological Evidence. Bangkok: Silpakorn University (in Thai).

2001 Report on the Excavation at Muang Fa Daed Song Yang, Kamalasai District, Kalasin Province. Bangkok: Silpakorn University (in Thai).

Kermel-Torres, Doryane

2004 Atlas of Thailand: Spatial Structures and Development. Chiang Mai: Silkworm Books.

Knapp, A. Bernard, and Wendy Ashmore

1999 Archaeological landscapes: Constructed, conceptualized, ideational, in Archaeologies of Landscape: Contemporary Perspectives: 1-33, ed. Wendy Ashmore and A. B. Knapp. Oxford: Blackwell Publishers.

KRAIRIKSH, PirIYA

1974 Semas with scenes from the Mahanipata-jatakas in the National Museum at Khon Kaen, in Art and Archaeology in Thailand: 35-100. Bangkok: Fine Arts Department.

Layton, Robert, And Peter Ucko

1999 Introduction: Gazing on the landscape and encountering the environment, in The Archaeology and Anthropology of Landscape: 1-20, ed. Peter Ucko and Robert Layton. London and New York: Routledge.

LORRILLARD, MiCHEL

2008 Pour une géographie historique du Bouddhisme au Laos [A historical geography of Buddhism in Laos], in Recherches Nouvelles sur le Laos/New Research on Laos: 113-181, ed. Yves Goudineau \& Michel Lorrillard, Vientiane-Paris: Ecole Française d'Extreme-Orient.

Marshall, J. H., A. Foucher, and N. G. Majumdar

1940 The Monuments of Sanchi. Calcutta: Survey of India Offices Heliozincograph.

MoOre, E.

1988 Moated Sites in Early North East Thailand. International Series No. 400. Oxford: British Archaeological Reports.

2007 Early Landscapes of Myanmar. Bangkok: River Books.

Murphy, Stephen A.

$2010 a$ Dvaravati period sema stones: Shifting meanings and definitions in archaeology, epigraphy, texts and religious re-use. Rian Thai: International Journal of Thai Studies 3:259-282.

$2010 \mathrm{~b}$ The Buddhist Boundary Markers of Northeast Thailand and Central Laos, 7th-12th Centuries CE: Towards an Understanding of the Archaeological, Religious, and Artistic Landscapes 
of the Khorat Plateau. Ph.D. diss. School of Oriental and African Studies, University of London. Electronic version available at http://eprints.soas.ac.uk/12204/.

2013 The distribution of sema stones throughout the Khorat Plateau during the Dvaravati period, in Unearthing Southeast Asia's Past: Selected Papers from the 12th International Conference of the European Association of Southeast Asian Archaeologists vol. 1:215-233, ed. Marijke J. Klokke and Véronique Degroot. Singapore: NUS Press.

SCHOpen, Gregory

1997 Bones, Stones, and Buddhist Monks: Collected Papers on the Archaeology, Epigraphy, and Texts of Monastic Buddhism in India. Vol. 2 of Studies in the Buddhist Traditions. Honolulu: University of Hawai'i Press.

SHAW, JULIA

2004 Nāga sculptures in Sanchi’s archaeological landscape: Buddhism, Vaiṣnavism, and local agricultural cults in Central India, first century BCE to fifth century CE. Artibus Asiae $64: 5-59$.

Shaw, Julia, and J. V. Sutcliffe

2001 Ancient irrigation works in the Sanchi area: An archaeological and hydrological investigation. South Asian Studies $17: 55-75$.

2003 Water management, patronage networks, and religious change: New evidence from the Sanchi Dam Complex and counterparts in Gujarat and Sri Lanka. South Asian Studies 19:73104.

Sisouphanthong, Bounthavy, and Christian Taillard

2000 Atlas of Laos: The Spatial Structures of Economic and Social Development of the Lao People's Democratic Republic. Copenhagen: NIAS.

Skilling, Peter

2003 Dvaravati: Recent revelations and research, in Dedications to Her Royal Highness Princess Galyani Vadhana Krom Luang Naradhiwas Rajanagarindra on her 80th Birthday: 87-112, ed. C. Baker. Bangkok: Siam Society.

SUPAJANYA, T., AND P. VANASIN

1983 The Inventory of Ancient Settlements in Thailand. Bangkok: Toyota Foundation.

SweARer, DONALD

1995 The Buddhist World of Southeast Asia. Albany: State University of New York Press.

ТАмвіан, S. J.

1984 The Buddhist Saints of the Forest and the Cult of Amulets. Cambridge: Cambridge University Press.

Thera, Nyanaponika, and Bhikkhu Bodhi, eds.

1999 Numerical Discourses of the Buddha: An Anthology of Suttas from the Anguttara Nikaya, trans. Nyanaponika Thera and Bhikkhu Bodhi. Sacred Literature Trust Series. Walnut Creek, CA: AltaMira.

Tilley, Christopher

1994 A Phenomenology of Landscape, Places, Paths and Monuments. Oxford: Berg.

WANGSUK, KHEMICA

2000 The Cultural Development in the Mun River Basin: A Case Study of the Archaeological Site at Muang Sema, Sung Noen District, Nakhon Ratchasima Province. M.A. thesis. Department of Archaeology, Silpakorn University (in Thai).

WOODWARD, HIRAM

1997 The Sacred Sculpture of Thailand. Bangkok: River Books.

2005 The Art and Architecture of Thailand, From Prehistoric Times through the Thirteenth Century. Leiden: Brill.

\begin{abstract}
This article employs the research paradigm of historical ecology to investigate the spread and development of early Buddhism in the Khorat Plateau during the Dvaravati period. The movement of this religion into the region was largely determined by preexisting settlement patterns, with moated sites being particularly important. The arrival of Buddhism also introduced monumental architecture and a definable art style. These moated
\end{abstract}


settlements were dependent on large-scale river systems such as the Mun and Chi, particularly in regard to water management, agriculture, transport, and communication. A study of the distribution of sema stones also provides evidence for the spread of Buddhism, while Buddha images carved into rock faces on mountaintops and evidence for rock shelters illustrate that the tradition of forest monks was functioning alongside the more established urban monasticism. The relationship between Buddhism and society is explored, illustrating how the arrival of this religion resulted in new cognitive and physical conceptions of the landscape best demonstrated by changes in settlement planning. Finally, it is shown that Buddhism did not function outside of society but existed in an interdependent relationship with both the lay community and local rulers, with patronage being granted in return for not only spiritual guidance but political legitimization. Keywords: Buddhism, historical ecology, urban monasticism, forest monks, Northeast Thailand, Central Laos, Khorat Plateau, Dvaravati, Chi and Mun Rivers, sema stones. 